\title{
“Gene-fouled or gene-improved?" - Media framing of GM crops and food in Hungary
}

\section{Lilla Vicsek*}

Institute of Sociology and Social Policy, Corvinus University of Budapest, Budapest, Hungary

Preprint version of article: Vicsek, Lilla (2012): “Gene-fouled or gene-improved?” Media framing of GM crops and food in Hungary, New Genetics and Society, iFirst, DOI:10.1080/14636778.2012.705513

* Correspondence should be addressed to: Lilla Vicsek, Institute of Sociology and Social Policy, Corvinus University of Budapest, Budapest, Közraktár u. 4-6., 1093. Hungary, telephone: + 36 1-482-7206, fax: +36 1-482-7348, e-mail: lilla.vicsek@uni-corvinus.hu.

Lilla Vicsek, Ph.D. conducts research on the gender culture of organizations, as well as research related to the sociology of science and technology at the Institute of Sociology and Social Policy at Corvinus University of Budapest. Her recent publications dealt with the media framing of stem cell research/treatment and the role this played in shaping audience understandings of the issue and appeared in Science Communication and in New Genetics and Society. She is currently conducting research on attitudes towards reproductive technologies in Hungary. 


\title{
“Gene-fouled or gene-improved?" - Media framing of GM crops and food
}

\section{in Hungary}

\begin{abstract}
This paper presents results from a research which analyzed the reporting on genetically modified crops and food in the Hungarian tabloids and political papers with the highest circulation from 1 May 2007 to 31 October 2009. Both quantitative and qualitative media analysis was conducted. It was found that in contrast to some Western countries the issue had low salience in the investigated period; it featured especially marginally in the tabloids. Two distinct valenced frames could be differentiated: a dominant ANTIGM (Threat) frame - which was particularly frequent compared to what has been found for some other countries, and a minority PRO-GM (Advancement and Benefits) frame. Despite a range of similarities with what had been reported by previous research from some other countries, argumentation on the GMO topic in the Hungarian press had several distinct characteristics, one of which was the relative prominence of economic arguments against the technology.
\end{abstract}

Keywords: media analysis, GM crops, GM food, genetically modified

\section{Introduction}

Due to socio-historical reasons, civil society is weak in Hungary compared to Western countries (Acsády and Ferencz 2008). Within this relatively weak civic sphere however, the environmental movement does carry some weight: it is among the most established environmental movements in Central and Eastern Europe (Harper 2004). Environmentalists in Hungary started to take up the issue of GM mainly in the second half of the nineties (Harper 
2004). Civic activists participated with experts and politicians in the GMO Roundtable, which contributed to the amendment of the law on gene technology in Hungary in 2006 (Darvas 2008).

Environmental organizations are, however, less embedded in society than their Western counterparts; public participation in environmental organization is low. The public shows less interest in the actions of the environmental organizations ${ }^{1}$ and in general towards post-material issues such as environmental causes (Inglehart and Welzel 2005). There is a low level of interest from the lay public in Hungary in the GM issue (Vicsek 2011a). At the same time, GM technology is not seen as a benign technology: findings of the 2005 Eurobarometer survey indicate that in 2005 the Hungarian public rated GM crops negatively - similarly to the citizens of many other European countries (Gaskell et al. 2006).

There have been turbulent debates in a number of societies world-wide on the issue of genetically modified crops (Shineha - Kato 2009). In contrast, in Hungary the GM issue was not high on the political or media agenda. Hungarian political news in the media is often dominated by the disputes between the different political parties; this is what makes top political news. But in the case of GM there was no great conflict between the parties: there was political agreement among the major parties that there should be a moratorium in Hungary on the cultivation of genetically modified MON810 corn. The fact that the political parties agreed was not heavily publicized and the GM topic did not become a hot political issue.

While the political sphere and most of the civic organizations are against GM cultivation in Hungary, there is division within the scientific sphere. A leading scientist of the pro-GM side is biotech researcher Dénes Dudits, president of the Barabás Zoltán Federation of Biotechnology, an association which calls for less strict regulation of GMO cultivation and use in Hungary. Members of the federation include some research organizations and several 
biotech companies - such as Monsanto and Syngenta (Dudits 2009). A prominent figure among scientists and experts who take a more cautious view of GM crops is Béla Darvas. He founded the GMO Roundtable in 2005 - which some pro-GM scientists regard as a biased, anti-GM organ. Both Dudits and Darvas have expounded their views in different media outlets.

Although the EU has allowed the cultivation of MON810 corn, Hungary - similarly to some other countries - has opted for a national safeguard clause. This clause came into effect in Hungary in 2005; up until the end of our examined period (the end of 2009) the cultivation of GM crops (for commercial purposes) was not allowed in Hungary ${ }^{2}$. The European Commission has several times introduced motions to lift this ban in Hungary - to date unsuccessfully.

There is by now abundant social scientific research on GM related topics, and a number of writings have appeared which contain systematic analysis of the media portrayal of GMOs (Augoustinos et al. 2010, Bauer 2005, Bauer et al. 2001, Cook et al. 2006, Hughes 2005, 2007, Hughes et al. 2008, Kohring and Matthes, 2002, Maeseele and Schuurman 2008, Maltese-Nehrbass et al. 2006, Marks et al. 2007, Nisbet and Huge 2006, ParalesQuenza 2004, Priest and Eyck 2003, Vilella-Vila and Costa-Font 2008). Research results have been reported from a range of countries: with some countries, such as the UK and US, being overrepresented, while others are underrepresented in the major international literature. Sociological aspects of the GM issue are an especially underresearched topic in Hungary, extremely little is known on this.

The aim of our exploratory research was to investigate how the press represented GM crops and food in Hungary: what the salience of the issue in the press was and what kind of valenced frames the press employed. We analyzed the coverage of the two political papers and the two tabloids with the highest circulation from 1 May 2007 to 31 October 2009. In this 
paper we will argue that despite a range of similarities with the reporting of some other countries, Hungarian coverage also had several distinct characteristics.

Previous research concentrating on other societies that have applied a frame analysis perspective in the case of GM focused mainly on a numerical analysis of the occurrence of the frames rather than giving a comprehensive in-depth, rich and nuanced description of the frames (Bauer 2005, Bauer et al. 2001, Kohring and Matthes 2002, Marks et al. 2007, Nisbet and Huge 2006, Parales-Quenza 2004, Priest and Eyck 2003) ${ }^{3}$. In our research, besides a quantitative analysis, a detailed qualitative analysis of the frames was also made.

We also included tabloids in our analysis, while much previous research investigating media frames on GM sampled only the elite press. Henderson and Kitzinger (1999) have argued that it can be relevant to include tabloids in media analyses and not just elite papers, as often different publics are reached by the different types of media outlets. Readership data on our analyzed newspapers support this assumption (GfK Hungária Market Research Institute and Szonda Ipsos Media Opinion and Market Research Institute 2007).

It is important to investigate the social aspects of genetic modification of crops, as it is a controversial technology that is applied in many areas around the world - and thus has the potential to affect the lives of many people. Hungarians typically eat food products which have some degree of GM content. Products containing more than 0.9 percent GMO content have to be labeled, and whilst there are basically no labeled products in the stores, many food products which are unlabeled contain some degree of GM material - in some cases even above the 0.9 percent labeling limit (Kasza-Lakner 2012). The issue of crop cultivation in Hungary being GM or non-GM is relevant for the country also because of the extent of the country's agricultural seed export.

Scholars of Science and Technology Studies and science policy experts have argued for some time that it is important to get the public engaged in scientific matters and increase 
their knowledge and democratic participation in science and technology issues (Király 2007). The European Commission (2009) also emphasizes the need for public engagement and the need to take into account in some ways the views of the public in science issues. The media can be an important source in resourcing lay discourse on science and technology topics. However, if the salience of these issues is low in the media - as is the case in Hungary with GM crops - and the public is not adequately informed of debates on dangers and benefits of technologies which exercise an effect on their lives, then lay people's range of scientific citizenship is impoverished.

\section{Theoretical background}

Day by day there are events in the world considered to be about genetic modification of crops, some of which appear in the media news whereas others are left out. The kind of events that are selected can contribute to different frames being applied in the media for the GM topic and of course the same event can be presented with different interpretations. Front stage and back stage media actors (Kitzinger 2009) can compete to ensure that their preferred frame dominates the portrayal of an issue.

Frames are an "essential feature of news" (Tuchman 1978, p. 193). Frames have been defined in a variety of ways (Entman 1993, Gamson 1992, Gitlin 2003, Iyengar 1991, Kitzinger 2007, Scheufele 1999), however an important shared aspect of many notions on framing is that frames are "coherent packages of information" (Schuck and de Vreese 2006, p. 6), and that not all elements of a frame need to be present in order to evoke recognition of the frame (Kitzinger 2007). In the paper we build on Entman's (1993, p. 52) concept of framing: "To frame is to select some aspects of a perceived reality and make them more salient in a 
communicating text, in such a way as to promote a particular problem definition, causal interpretation, moral evaluation, and/or treatment recommendation for the item described."

In our study we will be analyzing binary valenced, issue-specific news frames.

Valenced frames "evaluate political issues or situations in either positive or negative terms" (Schuck and de Vreese 2006, p. 6). Although there are some social scientists - such as Nisbet and Huge (2006) - who argue against the use of valenced frames, researchers from a range of disciplines have applied valenced news frame analysis (Schuck and de Vreese 2006). Shuck and de Vreese (2006) argue that Entman's understanding supposes that frames are always valenced - because of the element of moral evaluation present in it.

Frames applied on different topics are not necessarily binary, although they can be, if dichotomous rhetorical strategies can be observed in the texts. Kitzinger (2007) for example, in her analysis on frames used for embryo research, discerned a pro-embryonic stem cell research frame in which embryos were seen to be precious material for research and an antiembryonic stem cell research frame which argued for the embryo as human life that needs to be protected.

Some of the frames that frame researchers had developed have been issueindependent. These frames were developed in a way that they could be used for the analysis of different issues. On the other hand, many frames that had been applied by researchers similarly to the embryo stem cell research frames described above - had been issue-specific, i.e. only appropriate for the analysis of a certain issue. The advantage of the issue-specific type is that it contains a "high level of specialization and precision", but a disadvantage is the "lack of universality" (Dahinden 2002, p. 191). These characteristics thus have to be taken into account in the interpretation of our results.

Media frames can be relevant as they are one of the sources that can influence how the audience constructs an issue (Schuck and de Vreese 2006) - even if media influence can in 
some cases go in unexpected directions and some audience members might potentially develop an oppositional understanding of the media coverage (Hall 1980, Kitzinger 2002). The topic of technology and science is special in the sense that "on a day-to-day basis, many people do not have other sources of expert information or interpretation of scientific issues" (Crawley 2007, p. 341, Priest and Eyck 2003). However, this does not mean that the way people make sense of biotechnology necessarily echoes the media presentation. People can rely on other conversational resources in their discourses - such material learnt at school, their experiences in case of other topics from which they make logical inferences to the topic in question, etc (Hornig Priest 1994).

\section{Previous research on GM in the media}

A significant body of research has studied the frames that appeared in the media in connection with GM (Bauer 2005, Bauer et al. 2001, Kohring and Matthes 2002, Marks et al. 2007, Nisbet and Huge 2006, Parales-Quenza 2004, Priest and Eyck 2003). Bauer and his colleagues (2001, p. 41) based on their analysis of the elite press of 15 countries, which included the US, Canada and many European countries (but not Hungary), conclude that before 1996/1997 the press in most of these countries mostly "celebrated biotechnology in terms of progress and economic prospects" and applied frames linked to these. Over time, the analyzed press in most of these societies increasingly differentiated between medical and agrifood biotechnology: after 1996/97 agrifood biotechnology came to be presented more negatively, with risks and threats attributed to it more frequently than to medical applications and concern frames being more often applied linked to it than earlier.

Other more recent analyses of the UK, US, Spanish and Belgian press (employing diverse analytical perspectives - including analysis of frames) amongst others also highlight that after the late 1990s GM was often presented in the examined media outlets as a controversial issue (Augoustinos et al. 2010, Bauer 2005, Hughes et al. 2008, Maeseele and 
Schuurman 2008, Marks et al. 2007, Nisbet and Huge 2006, Vilella-Vila and Costa-Font 2008).

In the case of UK media coverage - which has been the focus of many qualitative media analysis research projects on GM news coverage - the following characteristics have been found by recent studies which have applied a range of qualitative methods:

- the public of the country portrayed as uniformly opposed to this biotechnology (Augoustinos et al. 2010);

- the UK government was often depicted as undemocratic: "determined to proceed with the introduction of GM farming in spite of public opposition" and as being under pressure from "big business" and the USA (Augoustinos et al. 2010, p. 9);

- science linked to GM was represented as a controversial field (Augoustinos et al. 2010);

- biotech companies were often depicted as a "powerful" industry - and in anti-GM writings as giant companies interested only in profit (Augoustinos et al. 2010);

- the topic was linked to other important political stories of the time, such as the Iraq invasion: the pro-US stance of the British government on GM was paralleled to that of its pro-US position on the Iraq invasion (Cook et al. 2006);

- a cluster of metaphors were present in connection with terrorism: bioterrorism was used to refer to the opponents in the dispute by both sides and GM crops were in some cases presented as a tool in fighting terrorists (for example a crop was presented which changed color when it was exposed to biological or chemical weapons) (Cook et al. 2006);

- there was frequent use of battlefield metaphors: disputes were often referred to as "wars" or "battle", an activity called an "attack" or an "invasion" (Cook et al. 2006); 
- nationalistic arguments were present in several ways: a cluster of metaphors was connected to impurity, contamination - which linked the topic with xenophobia and debates on immigration and asylum-seeking (Cook et al. 2006, Hughes 2005);

- the EU was represented either as a "threat to the UK, forcing genetically modified organisms into the country" - or as a "barrier, protecting UK citizens from the corrupt forces of the USA" (Hughes 2005, p. 251);

- Opposition to GM was caricatured as Luddite - which in the UK public debate has come to mean "dim-witted, irrational, bigoted, violent and badly organized opposition to all technology" (Cook et al. 2006, p. 26);

- references to science fiction, the symbolism of Frankenstein and science-fiction metaphors were also applied in the news reporting (Hughes et al. 2008);

- pro-GM proponents lost the battle for the terminology employed in the media (Hughes et al. 2008);

- GM reporting discussed emphatically decisions regarding the technology, controversies and the demonstrations, protests taking place (Hughes et al. 2008). There are some indications that similarly to the trend found by Bauer et al. (2001) for many other countries, the coverage of GM over time became more negative in Hungary (Harper 2004, Kasza-Lakner 2012).

Krista Harper, an anthropologist, besides reporting on ethnographic fieldwork among environmental activists related to GM in Hungary writes also on the media coverage in the late 1990s and early 2000s based on interviews and her impressions. According to her, prior to 1998 , there was very little media coverage of GM crops in Hungary. After 1998 and the Pusztai affair (this involved Hungarian-born biochemist Árpád Pusztai coming forward with research results which he interpreted as indicating the dangers of GM food) media reporting on GM focused more on controversial issues and became more negative (Harper 2004). 


\section{Data and methods}

We examined the press coverage for a period of two and a half years (from 1 May 12007 to 31 October 2009) in four dailies in Hungary: the two political papers and the two tabloids with the highest circulation. The investigated political papers were: Népszabadság - a leftwing, liberal political newspaper, Magyar Nemzet - a right-wing conservative political newspaper, and two tabloids: Blikk and Bors. The investigated tabloids reach a different segment of the population than political newspapers, readers of the political papers are of higher status (GfK Hungária Market Research Institute and Szonda Ipsos Media Opinion and Market Research Institute 2007). Hungary's daily with the highest circulation (not counting the free daily Metropol) Blikk, is one of the tabloids included in our sample, while the other three are also included in the top five dailies by circulation (among the top five is also a sports daily, which was left out of the analysis, as it contained no relevant articles) (Matesz - The Hungarian Audit Bureau of Circulations, 2009).

Articles were selected in two steps: first we electronically searched a database ${ }^{4}$ containing articles from these papers for the analyzed period using as search terms "genetic modification" and a wide range of related concepts (such as "GMO", "genetically improved", "genetically manipulated", etc.). Then from the resulting articles we selected all those which,

on reading, the coders (the author of this article and an independent $\operatorname{coder}^{5}$ ) found touched upon GM crops or GM food. This procedure resulted in 196 articles. In the following for reasons of simplification we often refer to them as GM or GMO articles, whereas they involve the narrower topic of crops or food.

First, a quantitative content analysis was conducted, where several aspects were coded into the statistical software SPSS by two coders (the author and the independent coder mentioned above). Which daily the article appeared in was coded. Related to the salience, the 
length of the part of the article dealing with the GM issue was coded (number of paragraphs), as well as the page the article started on. Frames to be applied in the analysis were determined inductively by the author of this article after consultations with the other coder based on the argumentation found in the articles of the study corpus. The argumentation was found to be binary, hence two valenced frames were adopted.

Articles were classified as belonging to:

(1) the PRO-GM frame category: if the coders had the impression that benefits and/or support of GM crops/food was more dominant in the article than risks, negative aspects and rejection of GM;

(2) the ANTI-GM frame category: if risks, negative aspects, rejection was felt by the coders to be more dominant than benefits and/or support, or if benefits were only attributed for the GM producers and this was rated negatively;

(3) the both frames (neither frame is dominant) category: if no obvious dominance in the case of the pro-and anti-aspects could be established, but both were present;

(4) the neither frame is present category: if benefits, support, positive aspects, risks, negative aspects, rejection of GM were not present in the article.

Intercoder agreement was tested on a sample of 50 articles, which were chosen randomly from the 196 articles. The intercoder reliability test using the conservative Cohen's kappa measure yielded acceptable results for the variables, with a value of .65 being the lowest for the more subjective frame variable (Landis and Koch 1977).

Besides a quantitative content analysis, a more fine-grained, in-depth qualitative frame analysis was also conducted. In choosing our analytical aspects for the qualitative analysis of the valenced frames, we built on the ideas of Entman (1993). In accordance, for the two frames the main characteristics were regarded to be: definition of the problem, sources of the 
problem and their moral evaluation, and the offered solutions. We also looked at what additional characteristics the texts belonging to the two frames demonstrated - taking into account the suggestions of Kitzinger (2007) related to the cues of what to analyze when examining frames (definition of concepts, use of labels, images, metaphors, who is invited to comment, etc.). Additional analytical dimensions based on the press articles involved were also developed.

Some of the verification strategies that Morse et al (2002, p. 18) advise to use were applied to enhance validity and reliability of the qualitative analysis ("methodological coherence", "analyzing data concurrently", etc.), as well as building into the qualitative analysis the lessons drawn from multiple coding of part of the texts (all articles were analyzed by the author and a subsample of 30 articles was coded also by an independent researcher).

\section{Findings}

The salience of the GM issue in the Hungarian press could be regarded as low in the investigated period, if we take into account the number of articles, their length pertaining to GM and their position within the papers. 60.2 percent of the 196 articles contained a maximum of one paragraph on the topic of GM crops/food (we decided to include amongst the research materials even those articles where the GM topic was touched upon only briefly, as it was interesting how GM was fitted into a wider discussion of other topics, for example with the help of the social degradation rhetoric). In this two and a half year period only three (!) of the articles appeared on the first page in the analyzed papers and the average beginning page number of the articles was 12.6 .

It is also relevant that the distribution of the GM articles into press outlets was very uneven. As it can be seen from Figure 1, the topic was treated especially marginally in the tabloids: out of all the articles only 16 are from the tabloids. 
Figure 1. about here

The ANTI-GM (Threat) frame was the dominant frame in the coverage: in 54.6 percent of the articles the ANTI-GM frame dominated. The PRO-GM (Advancements and Benefits) frame was much less frequent: it was the dominant frame only in 13.8 percent of the articles. Within the marginal coverage of the tabloids the presentation of the topic was less negative than that of the political papers (Table 1).

Table 1. about here

In the following we give an in depth description of a wider range of specific features of the two frames. The two frames contained distinct word usage, views on moral evaluation, ideas for solutions and on who was to blame, etc.

Problem definition. Within the minority PRO-frame the problem was held to be that there are regulatory and policy obstacles which stand in the way of scientific advancement. GM crops, which were argued were scientifically proven to be without great risks and which in many ways were beneficial, were not allowed as widely as they should be.

Involuntariness was an aspect present in the dominant ANTI-GM frame: that GM crops which were something that was risky and disadvantageous and attempts were being made to impose them on people/on Hungary.

Sources of the problem and their moral evaluation. An important element of risk issues and also frame analysis is who is to be blamed (Douglas 1992). Proponents of GM allocated blame to the (Hungarian) politicians who were against GM and who as a result 
decided on regulation held to be too strict by GM proponents. In these accounts these politicians were portrayed as backward and blinded by ideology and to be pursuing anti-GM policies to curry favor with the public. Politicians were also presented as relying in their arguments and decisions on faulty research and as themselves not having sufficient knowledge of GM.

Within the ANTI-GM frame causal agents for the problem were seen to be foreign bodies: GM producing multinational companies, in some cases the WTO, the USA, or the EC, or even the president of the European Commission: José Manuel Barroso. The USA was presented as the major supporter of the GMO industry and - especially in the conservative political paper - as employing aggressive policies and applying pressure in order to get the EU to open its markets to American GM products. The EC was portrayed as 'weak'-and particularly in the conservative paper - as being influenced by the GM lobby and as caving in to the pressure put on it by the USA directly or via the WTO. GM producers were portrayed in this frame as giant multinational companies whose goal is to monopolize the markets and maximize profit, often with the help of unethical methods. Negative social consequences were attributed to their operations in countries where GM crops were allowed.

Solutions offered. The solution to the problems was seen by proponents of the PROframe to be a regulation which allowed GM crops to be cultivated and sold more widely. They also argued for more money for research which was developing the GM technology. The proper authority source on which decisions regarding policy or regulations should be based was constructed in these accounts to be high ranking biotechnology scientists. This approach demonstrated considerable faith in the authority and capability of science. It represented the formative-normative, technical view of risks, often applied in risk assessment - that risks could be determined objectively by high-quality science, that they were essentially a scientific issue, which should not be polluted by factors such as ideology or personal interests. It 
represented the viewpoint that the scientific perspective should be given primacy - as it was the best perspective. The operation of the EFSA was regarded as being in accordance with this criterion. It was portrayed as consisting of scientists of international reputation.

In the ANTI-GM frame the goal was often declared to be freedom from any kind of GM. GM opponents argued for money for research that would examine risks in a "proper way", i.e. more thoroughly than a great body of previous research and also more “independently". By independent they meant research which was not financed or influenced by the GM lobby. It was argued that GM producers should give seeds for research purposes to independent researchers. In this frame the status attributed to science was not as high as in the case of the other frame. Also other viewpoints, not just scientific viewpoints, were seen as valuable and as such were regarded as proper sources that regulatory decision-makers should consider (for example the antipathy of the public towards GM).

Risks and benefits. Within the PRO-GM frame diverse arguments appeared on the benefits of GM. The minority of articles employing this frame saw GM production as a way of achieving environment-friendly technological progress, which could contribute to curing certain illnesses or to combating hunger or in the production of fuel, which would help a country's agriculture compete well on international markets and which gave higher profit and yielded well by producing crops resistant to disease, to lack of salt or water and to insects.

In the dominant ANTI-GM frame the focus was on diverse risks and negative aspects linked to GM. In this frame, GM was presented as a technology the European/Hungarian public was against, and on which there was a lack of adequate research, thus it was not known what the long-term consequences of its application would be as it potentially caused human health problems, harmed animal life and the environment. A prominent claim was that the cultivation of GM crops was not feasible economically in Hungary. This was supported by the following argumentation: 1. GM crops could not be sold on the markets - because of the 
negative sentiment of Hungarians and people of many other countries, 2. if GM cultivation was allowed in Hungary then all crops would have to be labeled whether they were GM or not, and this would entail costs, 3. the image of Hungarian agricultural products was best if it remained traditional, 4 . once GM cultivation was allowed on even a small piece of land irreversible genetic pollution could occur. Benefits attributed to GM crops by pro-GM proponents were recurrently contested by those opposed to GM. In the case of MON810 corn it was argued by opponents of GM that there was no point in cultivating this corn in Hungary as its primary benefit was protecting against a kind of moth which did not exist in Hungary.

Beneficiaries. The PRO-GM frame connected benefits to hungry people, farmers, the sick or consumers. Whether it was beneficial for multinational companies was basically missing from this discourse, or in one or two cases the argument appeared that the technology would not be able to survive if it was only good for multinational companies. On the other hand, if beneficiaries were raised in the ANTI-GM frame at all, mainly GM producing companies were mentioned - and this was often rated negatively.

Uses of GM. Within both frames GM crops featured dominantly as a food issue, but within the PRO-GM frame there was more emphasis on some other uses such as for fuel or medicine compared to the opposing frame.

Concept of genetic modification. It is possible to differentiate between broad and narrow concepts of genetic modification. The way genetic modification was defined was in connection with the frames applied. An attempt was made in the media by biotech researcher Dudits to popularize a pro-GM broad concept. He emphasized that not only those crops which are generally labeled nowadays as genetically modified crops are genetically modified, the scope was wider: there were other variants of plant breeding which can involve genetic modification of crops (such as hybridization), which are wide-spread, legal, accepted by the public and have been legal and wide-spread practice in Hungary for centuries, and are 
generally not regarded as genetic modifications in public discourse. This broad understanding was used sometimes in articles of the PRO-GM frame, but mainly in cases when Dudits was invited to comment. This understanding of GM entails a view that GM (understood broadly) is not a new method. In contrast, a narrow concept of genetic modification was predominant in the press - which defined it as a controversial new procedure which in some countries was allowed, in others prohibited. Another kind of broad concept of genetic modification also featured in the press which regarded GM negatively: in some reports applying the ANTI-GM frame, GM was used as an embodiment of current negative phenomena, it symbolized more than just genetic modification itself, rather the negative status of the globalized, modern world today.

Labels. Labels can be a site of contest in controversial issues (Hughes et al. 2008). Pro-GM proponents problematized the current practice of labeling, arguing that the most widely applied terms carry negative connotations. Some of them used these widespread terms in the media - while alluding to their problematic nature. One of the major proponents Dudits - argued in the media for the use of a different label. He proposed that the term "plants improved with gene technology" should be used, in order to emphasize that GM is a variant of improvement by breeding, and as breeding did not carry negative connotations. He lost the battle for language, as this term was used rarely, in only a portion of the writings of the PROGM frame. In the press the terms "gene treated", "gene modified", "genetically modified" were often used, and in some cases the abbreviations "GM" or "GMO", or the expression "modified with gene technology". "Gene-fouled" or "genetically manipulated", terms which carry negative connotations, were also used in some articles - dominantly within an ANTIGM frame.

Images. Among the images accompanying the texts of the articles, pictures of crops/seeds of crops that have been tampered with were most common in both frames. In the 
PRO-frame there were no pictures of crops that looked exceptionally beautiful or abundant; they mostly looked like ordinary crops - with an element of human intervention hinted at in the form of a test-tube before it, etc. In the ANTI-GM frame there were in some cases also pictures of seemingly damaged crops. Some pictures in the PRO-frame portrayed scientists who commented on the benefits of GM. Pictures belonging to the ANTI-frame were more varied, not just linked to the crop itself or to science, but showed also cases of protest actions or experts, politicians, activists, famous people who expressed a negative opinion on GM in the reporting. Anti-GMO demonstrations as topics hardly featured in the GM reporting at all and when they did appear, they were, with one exception, about foreign protests. It is interesting however, that the pictures accompanying articles on GM in several cases contained pictures of anti-GMO demonstrations - even if the topic of demonstrations did not come up in the article.

Images about here (Image 1, Image 2, Image 3, Image 4)

Rhetoric of progress or degradation. Scientists of the PRO-GM frame applied a rhetoric of technological progress whereby the major positive value was attributed to the advancement of science; they argued that technological progress was necessary and unstoppable. The GM issue was fitted into this discourse.

For opponents of GM, technological progress was not seen as an ultimate goal, GM was not fitted into a discourse on technological progress, rather in some cases a rhetoric of degradation appeared in the ANTI-GM frame. This rhetoric stressed negative societal changes and in some cases saw the GM producing corporations as culprits of these negative changes. In a few cases the rhetoric of degradation focused on the deterioration of food. 
Metaphors. Both sides saw the GM issue as a site of battle, in some cases they used war metaphors to convey the controversy between the two camps (battlefield, fight, war, victory).

Who is invited to comment. Part of the pro- and anti-GM writings were readers' letters: many of those who wrote in were experts of the topic. There were emotionally heated arguments in such writings from both sides. Some journalists also took an active part in the debate: Miklós Hargitai wrote many articles in a dramatic tone in which he expressed his distrust of GM. In articles applying mainly the PRO-GM frame scientists were asked to comment, in writings belonging to the ANTI-GM frame a range of people appeared who argued against GM, not only scientists, but representatives of civic and professional organizations, politicians and ministry officials, and activists. People who openly and officially represented biotechnology companies were not asked to comment in either frame. Rhetoric linked to research on GM. References to research investigating the risks of GM technology appeared in the reasoning applied by both proponents and opponents of GM. An asymmetrical evaluation of research appeared in the accounts of both sides: both camps claimed that the research results which supported the arguments of the other side are inadequate and removed it from the field of scientific legitimacy. They supported such criticism with a contingent rhetoric, whereas research with conclusions supporting their own views was not attacked on such a basis. In the contingent rhetoric scientific results and beliefs are depicted as being influenced by non-scientific factors such as personal inclinations, the social position or incompetence of the scientists (Gilbert and Mulkay 1984, Juanillo Jr 2001).

In our case pro-GM proponents constructed accounts whereby research with conclusions emphasizing risks was depicted as inadequate, not of high enough research standard, those who did such research were rated as trying to advance their career by riding the anti-GM tide. In contrast, research which did not conclude that there were relevant 
harmful effects of GM was portrayed as being of international standard, it was not attacked, its results were accepted and the interests of the scientists involved were not questioned. Thus, in these cases an empiricist repertoire was employed - which depicted scientists' actions as "generic responses to the realities of the natural world" (Gilbert and Mulkay 1984, p. 57).

Those in opposition to GM on the other hand reflected on the contingent nature of results only in the case of research which they held to report on no relevant risks. These research projects appeared in the anti-GM accounts as biased and under the influence and funding of the GMO lobby. It was argued that these pieces of research are inadequate as they could not deal with long term effects of GM - more concretely with possible long term risks as it was not supposed that possible benefits would emerge later that had not been measured earlier. Even though science as the only field for an authoritative voice was questioned in the ANTI-GM frame, those research results were accepted as support for their statements which were interpreted as demonstrating the risks of GM.

Excerpts exemplifying some typical elements of the PRO-GM frame

Quotations from an article written by Dénes Dudits (biotech researcher) that appeared in the left-wing/liberal Népszabadság:

"It says a lot when we can hear a chorus of opinions from high-ranking officials or politicians that have nothing to do with the scientific arguments that have appeared in elite international journals. It is evident that behind the stock phrases there is a lack of knowledge of the facts. It is here that the world of science and the ideological battlefields diverge."

"A whole series of scientific articles and papers confirm that gene splicing can greatly improve the efficiency of bio-energy production from plants. We are witnessing the development of a new industry that produces medicines from GM plants... Drought-tolerant 
GM plants that utilize water more efficiently will be very important actors in the agriculture of the future."

"It is really difficult to understand why we do everything we can to exclude Hungarian society from the economic advantages offered by green bio-technology and from enjoying the environmental protection advantages. Opposition to gene technology offers a few politicians and mediocre researchers a career opportunity for a short while. But fortunately the mills of science cannot be stopped and we will be forced to see that we have no chance for a competitive agriculture without high-tech developments.” (Népszabadság, 14 March 2009, p. 12)

Excerpts exemplifying some typical elements of the ANTI-GM frame:

Quotations from an opinion piece written by Miklós Hargitai (science journalist) in the leftwing/liberal Népszabadság:

"Those with an interest in the distribution of gene-modified varieties in Europe are waging a strange war. They do not recognize the environmental risks (that are being proved one after the other to represent real dangers), they do not assist the investigations but rather hinder them. And they have never provided unequivocal proof that the introduction of the modified plants would bring a demonstrable advantage for anyone (apart from the producers). At the same time they frequently refer to the restriction of free trade (at the WTO), and to barriers to the free flow of goods (at the EU). At the moment the counter-arguments are much more convincing. In the developed countries the majority of consumers reject GM food, while even the politicians (the Hungarians) who often bow to the lobbying power of the multinationals admit that freedom from gene manipulation is a competitive advantage for export-oriented 
agriculture. It is therefore clear what we would risk by allowing in the modified varieties, but what we would win with it remains unclear. And although only a few bio-technology firms stand opposed to practically the entire world, the outcome of the struggle is still doubtful." (Népszabadság, 3 April, 2008, p. 14)

Excerpt from an article in the right-wing/conservative Magyar Nemzet:

"The pressure is very strong. The multinationals' lobby is not used to refusal. America, the home of gene-modified plants, is now GMO-polluted. Now it is in its interest to drag others along with itself. Standing opposed to them is the small band of the Hungarian green lobby politicians, experts, activists - who are not retreating. Of course, they are not alone, the links of the chain are gradually joining up, one after the other countries large and small are waking up."

(Magyar Nemzet, 29 January 2008, p.16)

Excerpt from an essay in the tabloid Bors:

"The future began a long while ago, it is far from certain nowadays that potato soup is really potato soup. It may be a GMO - a genetically modified product. Our poet tasted this expression with disgust. Because if we no longer know what is on our plate, how can we be certain of anything?"

(Bors, 18 September 2009, p.13)

\section{Discussion}

Our findings showed that the salience of the GM topic was low in the analyzed papers for the investigated period. In comparison with some Western European countries the GMO topic 
was lower on the agenda of the analyzed Hungarian media outlets: it hardly ever made headline news. The coverage was small in number compared to what has been reported by recent research for several other countries, for example the UK (Cook et al. 2006).

We found a great difference in the quantity of coverage between the different types of media outlets: the tabloids had far less items on the topic. This had the important consequence that consumers of the tabloids received minimal information on the topic from these sources.

Within the press coverage GM emerged as a debated issue, with two valenced frames, of which the ANTI-GM (Threat) frame was more dominant than the PRO-GM (Advancement and Benefits) frame. Compared to what has been found in recent media analyses for some other countries, such as the US and the UK (Cook et al. 2006, Marks et al. 2007), in Hungary the ANTI-GM frame was particularly frequent: it appeared in close to four times as many articles as the PRO-GM frame. While in the U.S. and the UK, recent previous research has found that there were papers which wrote on the topic extensively and at the same time dominantly in a positive light (Cook et al. 2006, Maltese-Nehrbass et al. 2006), this was not true for any of our analyzed papers: the political papers had a very negative stance toward the topic, the tabloids were less negative, but they contained hardly any coverage.

Possible reasons for the low salience of the issue in the media include the lack of interest of the Hungarian public in environmental, post-material issues (Inglehart and Welzel 2005, Karácsony 2001) - which can influence what gets published as journalists and editors might want to cater to what they believe the public is interested in. The low salience of the topic can also be partly attributed to the fact that for the political parties publicizing news on this was low on the agenda. It was not a hot political domestic issue as it did not lend itself to a kind of presentation where Hungarian political parties campaign for their own viewpoint being better than that of other parties - because of the political agreement between the parties on the issue. 
A possible explanation behind the much smaller extent of coverage in the tabloids is that the topic does not so easily lend itself to a soft news focus with Hungarian relevance as some other topics do (Vicsek 2011b, Vicsek and Gergely 2011). Basically all articles that we encountered were "serious" hard news articles. In an earlier research we found that coverage of another biotechnology - stem cells treatments - was much higher in the tabloids and that a considerable part of those writings were soft news articles on the drama of individual patients (Vicsek 2011b, Vicsek and Gergely 2011).

The argument that negative news would dominate the GM issue because of the fact that the media favors negative news, cannot be the major explanation: as other biotechnologies, such as stem cell research and treatment in certain time periods had been portrayed in a very positive light in Hungary (Vicsek 2011b, Vicsek and Gergely 2011).

The dominance of the ANTI-GM frame can be attributed partially to the successful frame sponsorship of that part of the political elite which is engaged in these matters and to some degree the frame sponsorship of civic and environmental organizations.

Another possible reason for the negative coverage is the negative sentiment of many Hungarian journalists. Biochemist, Venetianer (2010) traces this back to the qualifications of the journalists writing on the topic: they mainly have qualifications in the humanities. According to his argument people with these types of qualifications may tend more to favor green arguments as opposed to arguments of technocrats.

The conservative political paper was even more negative on the issue than the leftwing political paper, as the former could easily synchronize anti-GM sentiment with the antiAmerican, anti-multinational company, anti-globalization nationalistic ideology it propagates - which is characteristic of the right-wing parties in Hungary (even of the moderate Fidesz, although to a lesser degree than the extremist Jobbik). This might represent a difference compared to some Western European countries where anti-globalization, anti-American 
sentiment is in some cases more strongly present in the leftist papers and within the views of left-wing parties ${ }^{6}$.

Comparing results of our qualitative framing analysis with findings of qualitative studies in the UK that we have discussed in the paper in the section on previous research projects, a range of similar elements can be located, as well as several differences. In contrast to what has been found for the UK coverage (Augoustinos et al. 2010, Cook et al. 2006, Hughes 2005, Hughes et al. 2008), in the Hungarian press portrayal of GM: demonstrations were a marginal topic, the public and government were presented as having the same view on the GM issue, the topic was not connected to the political issues of mass migration, terrorism or Iraq, and the symbolism of Frankenstein (or other references to science fiction) was basically absent.

The marginal presentation in the press of demonstrations is partly due to the fact that there are fewer environmental demonstrations in Hungary than for example in Western Europe. In the case of the GM topic an additional reason for the low number of demonstrations was that more demonstrations took place in the case of topics on which there was a difference between the viewpoint of green organizations on the one hand and the political parties and the government on the other. Instead of demonstrations many organizations just gave out statements to the media on GM. That foreign demonstrations were marginally represented can be explained to a degree by the focus of the media on domestic events. It is also true that if demonstrations in Hungary did take place on the GM topic, this did not mean they were necessarily covered by the major papers.

There are indications that possibly science-fiction metaphors are less present in the Hungarian media with respect to other topics as well - not just linked to the GM topic (Vicsek 2011b, Vicsek and Gergely 2011). 
Major differences of the Hungarian GM coverage in comparison to that of several Western countries include anti-GM arguments related to economics. Arguments that absence of GM cultivation is best economically for Hungary appeared strongly in the Hungarian press, while earlier research found that the elite press of many countries connected the GM topic to a considerable degree to frames of economic prospects, to business opportunities (Bauer et al. 2001). According to experts, even in recent years economic arguments against GM are marginal in Western countries in the media.

It is not possible to tell whether several of the characteristics that we had observed for the valenced frames in Hungary were typical or untypical for the foreign press, as other research did not report on those analytical aspects.

Our research results have relevance in relation to the theoretical dilemmas on 'risk society'. Beck (1992, p. 71) argued that the public could win back "the autonomy of their judgements" if risks of the technologies were publicized. Assessing the role of the media in this respect, we can state that within the small press coverage of the issue many risks of GM crops and food that were identified as such by civic organizations, scientists were present. The political papers performed better in this respect than the tabloids. However, the low salience of the topic in the media is a potential limitation on how much information the public can get from these sources.

According to some scholars, science - or at least some fields of science - are becoming increasingly medialized. Shafer (2009) distinguishes three dimensions of medialization: 1. coverage extensifies, 2. it becomes more diverse in terms of actors and content, 3. it becomes more controversial. The presentation of GM in the Hungarian papers does show that a range of actors commented on science, and non-scientific aspects entered into the discussions on interpretation of research results, as well as science in connection with GM being presented as a controversial issue. However, we cannot talk of medialization in the 
sense that GM was not a "hot issue", its coverage was not extensive enough to talk of it being extensified compared to earlier periods.

Constraints of the paper include that only four newspapers were analyzed. There are some indications that the coverage of GM in other press outlets and on television in the analyzed period might be similarly of low salience and dominantly negative within Hungary and for the arguments present in other media outlets to be similar ${ }^{7}$.

\section{Acknowledgments}

The author would like to express her gratitude to Jenny Kitzinger and to Martin W. Bauer for their constructive suggestions linked to the research. The research project reported in the paper was funded by the Hungarian Scientific Research Fund (OTKA), and the author was supported in her work during the project by the Hungarian Academy of Sciences with a János Bolyai Grant.

\section{Notes}

1 Besides some written work (which is referred to), insights into the Hungarian context in the Introduction and the Discussion are partly also based on study of the legal regulation and on interviews with GM experts Tímea Vértes (lead consultant at the Ministry of Agriculture and Rural Development, Biotechnology Department, Secretary of the gene technology authority of the ministry), Béla Maczák of the Hungarian Food Safety Office, Pál Venetianer (biochemist, molecular biologist, former president of the Gene Technology Advisory Committee, author of the book entitled “Genetically modified crops? What are they good for?”), Márton Vay (media spokesman for Greenpeace Hungary) and on consultations with Balázs Tömöri (campaign coordinator, Greenpeace Hungary), Sándorné Jellen (chief senior consultant, Hungarian Chamber of Agriculture); Zsuzsa Szentgyörgyi (freelance science writer), Ferenc Vicsek (journalist, editor-in-chief of Klubrádió), 
Miklós Hargitai (science journalist, author of many articles on the GM topic). The interviews were conducted by Júlia Gergely (following guidelines set by the author) and the author.

${ }^{2}$ Since then, the conservative Hungarian government added the rejection of genetically modified crops as one of the elements of the Fundamental Law that was accepted by the Parliament on April 18, 2011 (this law can be changed only with the agreement of $2 / 3$ of the votes).

${ }^{3}$ An exception is the research of Hughes et al. (2008) which contained some elements of a qualitative frame analysis.

${ }^{4}$ The articles were obtained from the electronic database of Observer Budapest Médiafigyelö Kft.

${ }^{5}$ The independent coder was Zsófia Melinda Cseri.

${ }^{6}$ This aspect was mentioned by Pál Venetianer in the expert interview.

${ }^{7}$ Several of our expert interviewees voiced the opinion that the coverage was negative overall in the media and of low salience and that our description of the GM debate based on the four newspapers is very similar to what took place according to their impressions in other media outlets. This can also hypothesized based on our study of the transcripts of the Hungarian television news programs available in the electronic database of Observer (taking into account of course the risk that it is problematic that no images were available for the television programs as there is a chance that images might be in contradiction to the text). 


\section{References}

Acsády, J., and Ferencz, Z., 2008. Perception and Attitudes towards Biotechnology in Hungary. In: F. Molfino and F. Zucco, eds. Women in Biotechnology: Creating Interfaces. Springer, 93-106.

Augoustinos, M., Crabb, S., and Shepherd, R., 2010. Genetically modified food in the news: media representations of the GM debate in the UK. Public Understanding of Science, 19(1), 98-114

Bauer, M. W., 2005. Distinguishing Red and Green Biotechnology: Cultivation Effects of the Elite Press. International Journal of Public Opinion Research, 17(1), 6389.

Bauer, M. W., Kohring, M., Allansdottir, A., and Gutteling, J., 2001. The dramatisation of biotechnology in elite mass media. In: G. Gaskell and M. W. Bauer, eds. Biotechnology 1996-2000: The years of controversy. London: Science Museum, $35-52$.

Beck, U. 1992. Risk society: towards a new modernity. London: Sage Publications.

Cook, G., Robbins, P. T., and Pieri, E., 2006. "Words of mass destruction": British newspaper coverage of the genetically modified food debate, expert and nonexpert reactions. Public Understanding of Science, 15(1), 5-29.

Crawley, C. E., 2007. Localized debates of agricultural biotechnology in community newspapers - A quantitative content analysis of media frames and sources. Science Communication, 28(3), 314-346.

Dahinden, U., 2002. Biotechnology in Switzerland: Frames in a Heated Debate. Science Communication, 24(2), 184-197. 
Darvas, B., 2008. A GMO-Kerekasztal története, ülésrendje és kézirat-készítési szabályai. Available from http://www.bdarvas.hu/gmo/idn39 [Accessed 10 September 2011].

Douglas, M., 1992. Risk and Blame. Essays in cultural theory. London: Routledge.

Dudits, D., 2009. 10 év a hazai biotechnológia szolgálatában: Mérlegen a Barabás Zoltán Biotechnológiai Egyesület. Available from http://zoldbiotech.uw.hu/cikk/egyesuletrol 09 11.pdf [Accessed 10 September 2011].

Entman, R. M., 1993. Framing - toward Clarification of a Fractured Paradigm. Journal of Communication, 43(4), 51-58.

European Commission, 2009. Challenging Futures of Science in Society-Emerging trends and cutting-edge issues. Luxembourg: Publications Office of the European Union.

Gamson, W. A., 1992. Talking politics. Cambridge [England]: Cambridge University Press.

Gaskell, G., et al., 2006. Europeans and biotechnology in 2005: Patterns and trends. Final Report on Eurobarometer 64.3. Available from http://ec.europa.eu/research/biosociety/pdf/eb_64_3 final_report_second_editio n july 06.pdf [Accessed 10 September 2011].

GfK Hungária Market Research Institute, and Szonda Ipsos Media Opinion and Market Research Institute, 2007. Mindenki olvas - Tömegeket és speciális célcsoportokat is elér a nyomtatott sajtó [All read-Masses and special target groups are both reached by the print media] [Electronic Version], 2009. Available from 
http://www.gfk.com/imperia/md/content/gfk_hungaria/pdf/press_extra_h/press extra 20070828_h.pdf [Accessed 10 September 2011].

Gilbert, G. N., and Mulkay, M., 1984. Opening Pandora's box: A sociological analysis of scientists' discourse. Cambridge [England]: Cambridge University Press.

Gitlin, T., 2003. The whole world is watching: mass media in the making \& unmaking of the New Left. Berkeley, CA: University of California Press.

Hall, S., 1980. Culture, media, language: working papers in cultural studies, 1972-79. London: Hutchinson; Centre for Contemporary Cultural Studies, University of Birmingham.

Harper, K., 2004. The genius of a nation versus the gene-tech of a nation: Science, identity, and genetically modified food in Hungary. Science as Culture, 13(4), 471-492.

Henderson, L., and Kitzinger, J., 1999. The human drama of genetics: 'hard' and 'soft' media representations of inherited breast cancer. Sociology of Health \& Illness, 21(5), 560-578.

Hornig Priest, S., 1994. Structuring public debate on biotechnology. Science Communication, 16(2), 166-179.

Hughes, E., 2005. The contaminated risk of GM crops: nationalism and the genetic modification debate. Journal of Public Affairs, 5(3-4), 251-262.

Hughes, E., 2007. Dissolving the nation: Self-deception and symbolic inversion in the GM debate. Environmental Politics, 16(2), 318-336.

Hughes, E., Kitzinger, J., and Murdock, G., 2008. Media Discourses and Framing of Risk. Working Paper 27. Available from http://www.cardiff.ac.uk/jomec/resources/KitzingerWkPaper27.pdf. [Accessed 10 September 2011]. 
Inglehart, R., and Welzel, C., 2005. Modernization, Cultural Change and Democracy. New York: Cambridge University Press.

Iyengar, S., 1991. Is anyone responsible?: how television frames political issues. Chicago: University of Chicago Press.

Juanillo Jr, N. K., 2001. The risks and benefits of agricultural biotechnology: can scientific and public talk meet? American Behavioral Scientist, 44(8), 12461264.

Karácsony, G., 2001. Értékek és választások [Values and choices]. Educatio (3), 504516.

Kasza, G., \& Lakner, Z., 2012. Social Trenches in the GM Food Battlefield: Experiences of a Survey Series in Hungary. In P. Robbins (Ed.), Exploring Central and Eastern Europe's Biotechnology Landscape. New York: Springer.

Király, G., 2007. Democratization of Science and Technology in Europe. Participation of Citizens in a Post-national community. Ph.D. értekezés, Elte, Budapest.

Kitzinger, J., 2002. Impacts and Influences. Media influence revisited: an introduction to the 'new effects/influence research'. In: A. Briggs and P. Cobley, eds. The media: an introduction. 2nd edition. New York: Pearson Education, 272-281.

Kitzinger, J., 2007. Framing and frame analysis. In: E. Devereux, ed. Media studies: key issues and debates. London: Sage, 134-161.

Kitzinger, J., 2009. Risk, news coverage and public responses. Paper presented at the 'Managing the Social Impacts of Change from a Risk Perspective' Conference. Available from http://www.kent.ac.uk/scarr/events/beijingpapers/Kitzinger.pdf [Accessed 10 September 2011]. 
Kohring, M., and Matthes, J., 2002. The face(t)s of biotech in the nineties: how the German press framed modern biotechnology. Public Understanding of Science, $11(2), 143-154$.

Landis, J. R., and Koch, G. G., 1977. The measurement of observer agreement for categorical data. Biometrics, 33, 159-174.

Maeseele, P. A., and Schuurman, D., 2008. Biotechnology and the Popular Press in Northern Belgium: A Case Study of Hegemonic Media Discourses and the Interpretive Struggle. Science Communication, 29(4), 435-471.

Maltese-Nehrbass, M., et al., 2006. Nationwide Newspaper Coverage of Genetically Modified Foods: A Community Structure Approach. Paper presented at the Conference Papers -- International Communication Association.

Marks, L. A., et al., 2007. Mass media framing of biotechnology news. Public Understanding of Science, 16, 183-203.

Matesz - The Hungarian Audit Bureau of Circulations. (2009). Public circulations data. Retrieved 3.10.2009, from http://en.matesz.hu/data/

Morse, J. M., et al., 2002. Verification Strategies for Establishing Reliability and Validity in Qualitative Research [Electronic Version]. International Journal of Qualitative Methods, 1, 13-22. Available from http://ejournals.library.ualberta.ca/index.php/IJQM/article/view/4603/3756 . [Accessed 10 September 2011].

Nisbet, M. C., and Huge, M., 2006. Attention cycles and frames in the plant biotechnology debate - Managing power and participation through the press/policy connection. Harvard International Journal of Press-Politics, 11(2), $3-40$. 
Parales-Quenza, C. J., 2004. Preferences need no inferences, once again: germinal elements in the public perceptions of genetically modified foods in Colombia. Public Understanding of Science, 13(2), 131-153.

Priest, S. H., and Eyck, T. T., 2003. News Coverage of Biotechnology Debates. Society, 40(6), 29-34.

Schafer, M. S., 2009. From Public Understanding to Public Engagement: An Empirical Assessment of Changes in Science Coverage. Science Communication, 30(4), 475-505.

Scheufele, D. A., 1999. Framing as a theory of media effects. Journal of Communication, 49(1), 103-122.

Schuck, A. R. T., and de Vreese, C. H., 2006. Between Risk and Opportunity. European Journal of Communication, 21(1), 5-32.

Shineha, R., \& Kato, K., 2009. Public engagement in Japanese policy-making: a history of the genetically modified organisms debate. New Genetics and Society, 28(2), 139-152.

Tuchman, G., 1978. Making news: a study in the construction of reality. New York: Free Press.

Venetianer, P., 2010. A GM növények (és élelmiszerek) társadalmi elutasitásának okai [Why are GM plants (and foods) rejected by the public?]. Paper presented at the GMO Polemic conference, Pannon University, Keszthely, Hungary.

Vicsek, L., 2011a. Audience Discussion on GM crops in Hungary and the Role of the Media. OTKA Research Report. Manuscript, Budapest, Hungary.

Vicsek L., 2011b. Costs and benefits of stem cell research and treatment: media presentation and audience understanding in Hungary. Science Communication, 33(3), 309-340. 
Vicsek, L. and Gergely, J., 2011. Media presentation and public understanding of stem cells and stem cell research in Hungary. New Genetics and Society, 30 (1), 1-26.

Vilella-Vila, M., and Costa-Font, J., 2008. Press media reporting effects on risk perceptions and attitudes towards genetically modified (GM) food. Journal of Socio-Economics, 37(5), 2095-2106. 
Figure 1. Number of articles in the political papers and tabloids.

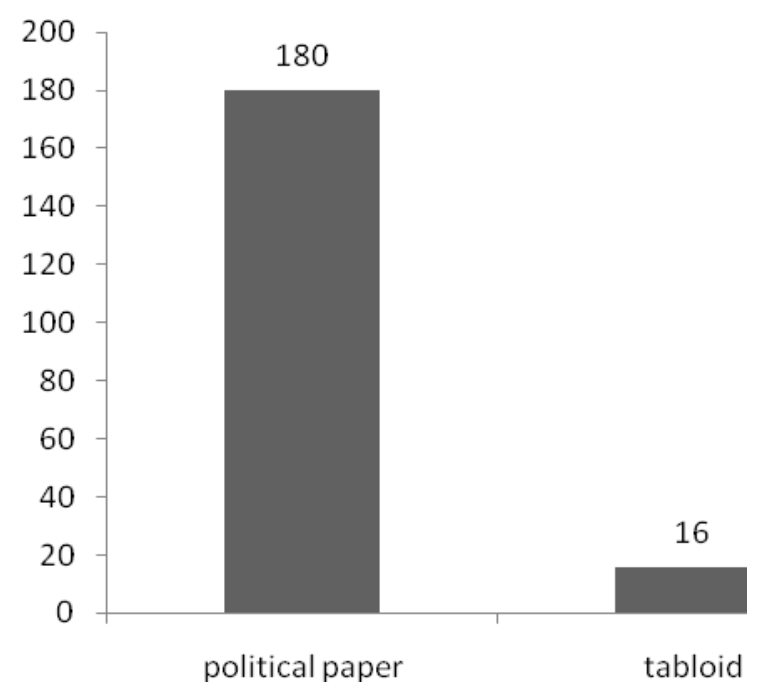

Table 1. Articles employing the ANTI- and PRO-GM frames in the political papers and the tabloids

\begin{tabular}{|c|c|c|c|c|c|}
\hline & $\begin{array}{l}\text { Dominantly } \\
\text { ANTI-GM frame } \\
\text { No. of articles } \\
(\%)\end{array}$ & $\begin{array}{l}\text { Both frames } \\
\text { No. of articles } \\
(\%)\end{array}$ & $\begin{array}{l}\text { Neither frame } \\
\text { No. of articles } \\
(\%)\end{array}$ & $\begin{array}{c}\text { Dominantly } \\
\text { PRO-GM frame } \\
\text { No. of articles } \\
(\%)\end{array}$ & $\begin{array}{c}\text { Total } \\
\text { No. of articles } \\
(\%)\end{array}$ \\
\hline $\begin{array}{l}\text { Political } \\
\text { papers }\end{array}$ & $\begin{array}{r}101 \\
(56,1 \%)\end{array}$ & $\begin{array}{r}40 \\
(22,2 \%)\end{array}$ & $\begin{array}{r}16 \\
(8,9 \%)\end{array}$ & $\begin{array}{r}23 \\
(12,8 \%)\end{array}$ & $\begin{array}{r}180 \\
(100,0 \%)\end{array}$ \\
\hline Tabloids & $\begin{array}{r}6 \\
(37,5 \%)\end{array}$ & $\begin{array}{r}3 \\
(18,8 \%)\end{array}$ & $\begin{array}{r}3 \\
(18,8 \%)\end{array}$ & $\begin{array}{r}4 \\
(25,0 \%)\end{array}$ & $\begin{array}{r}16 \\
(100,0 \%)\end{array}$ \\
\hline Total & $\begin{array}{r}107 \\
(54,6 \%)\end{array}$ & $\begin{array}{r}43 \\
(21,9 \%)\end{array}$ & $\begin{array}{r}19 \\
(9,7 \%)\end{array}$ & $\begin{array}{r}27 \\
(13,8 \%)\end{array}$ & $\begin{array}{r}196 \\
(100,0 \%)\end{array}$ \\
\hline
\end{tabular}


Image 1. Picture of corn seeds in vials from an article about genetically modified crops that appeared in the daily Népszabadság (4 June 2008, photo taken by Bernadett Szabó)

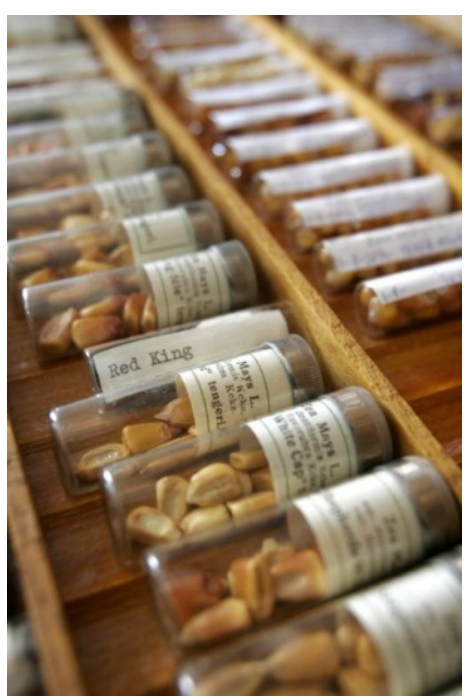

Image 2. Illustration accompanying an article on GMOs in the daily Népszabadság made by cartoonist Marabu (17 April 2008). The caption reads: "There is a problem. The experimental tomato is successfully defending itself not just against pests and weeds, but against harvesters too."

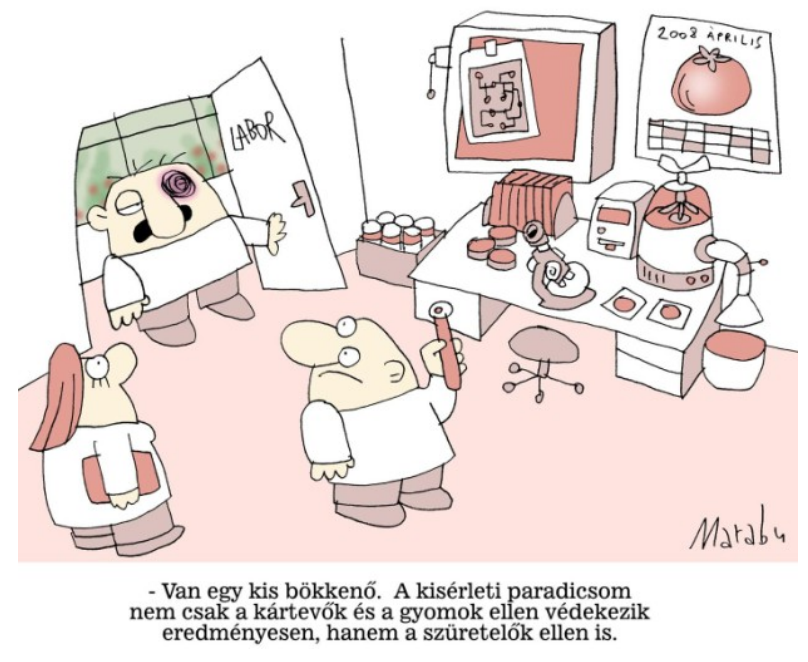


Image 3. Picture showing a foreign protest action against GMO-s in the daily Magyar Nemzet (17 October 2007)

I0

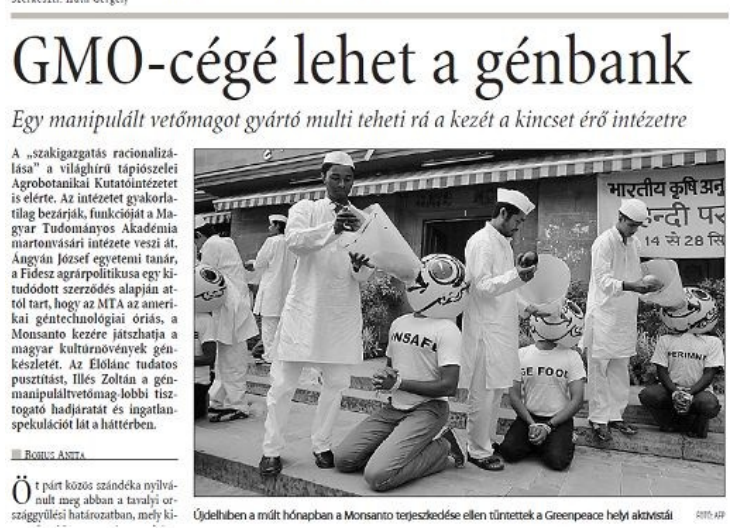

Image 4. Picture showing a single plant in a field in an article in the daily Magyar

Nemzet (6 May 2009) that argues that some GM crops did not produce good yields in South Africa

\section{Magtalan kukorica Dél-Afrikában}

A gazdák üres csöveket arattak, az amerikai Monsanto multicég magyarázkodik

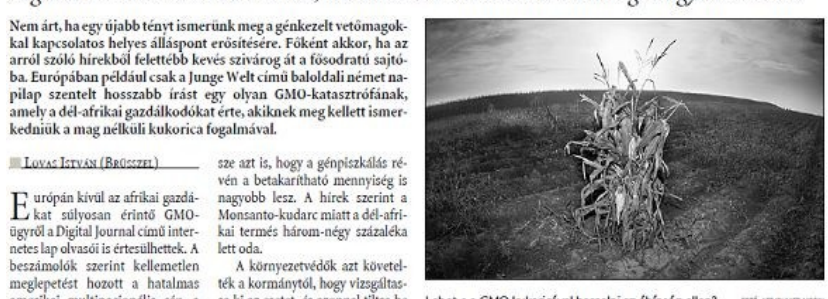

